\title{
Trueperella (Arcanobacterium pyogenes) in Farmed White-Tailed Deer ${ }^{1}$
}

\author{
Kathryn D. Pothier, Katherine A. Sayler, and Samantha M. Wisely²
}

\section{What is trueperella?}

Trueperella is a bacterium that can cause lesions in multiple areas of the body including the lungs, mouth, skin, and liver. It is a common cause of abscesses and pneumonia in deer. It also causes lesions on the face, ears, neck, lungs, and lymph nodes. It is one of the types of bacteria that is known to contribute to the disease lumpy jaw. In young fawns, it is a common cause of mortality (Ribeiro et al. 2015).

\section{How is trueperella transmitted in deer?}

This organism is a normal inhabitant of the intestinal tract of deer, cattle, pigs, and other ruminants. Sick animals shed the bacteria in their feces, contaminating their pens. Deer become infected by eating contaminated feed or dirt. Animals can also become infected through open cuts and wounds in their skin, and the bacteria can be transmitted by flies (Hogan et al. 1999). Although this bacterium can live in the intestines of animals without harm, if it migrates into other areas of the body and proliferates in different organs, it becomes pathogenic.

\section{Is trueperella contagious?}

Yes, but usually via contact with infected soil. Animals typically ingest infected soil or rub that soil into open wounds. Flies can also transmit the bacteria from animal to animal. It is possible to transmit the bacteria directly through mucous membranes and open wounds during animal-to-animal contact.

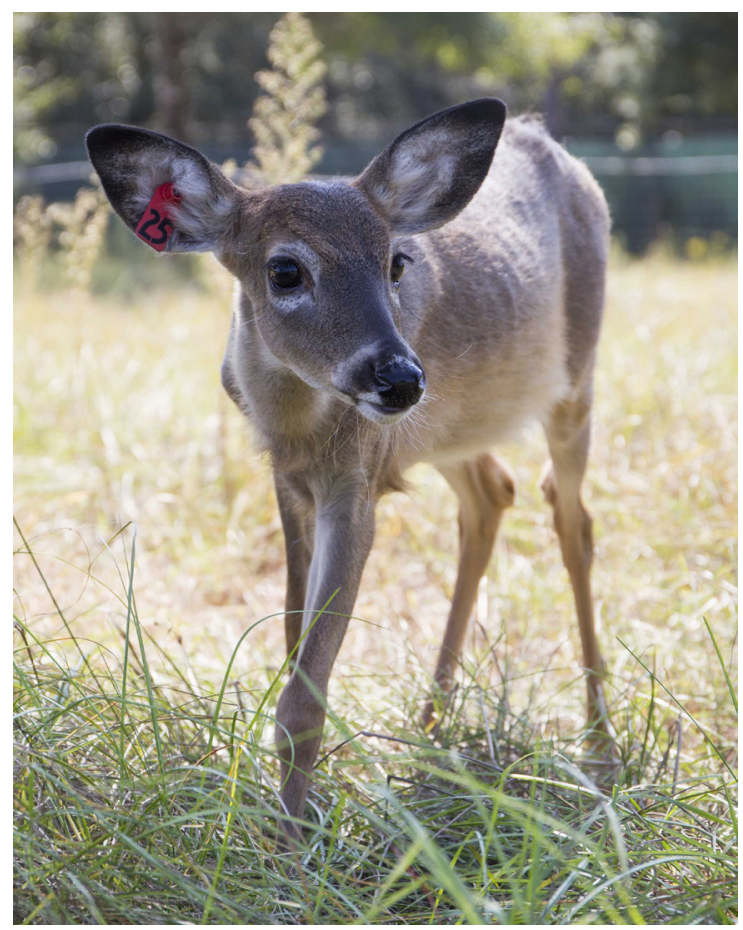

Credit: Tyler Jones, UF/IFAS

1. This document is WEC382, one of a series of the Department of Wildlife Ecology and Conservation, UF/IFAS Extension. Original publication date December 2016. Visit the EDIS website at http://edis.ifas.ufl.edu.

2. Kathryn D. Pothier, graduate research assistant; Katherine A. Sayler, assistant research professor; and Samantha M. Wisely, associate professor; Department of Wildlife Ecology and Conservation, UF/IFAS Extension, Gainesville, FL 32611.

The Institute of Food and Agricultural Sciences (IFAS) is an Equal Opportunity Institution authorized to provide research, educational information and other services

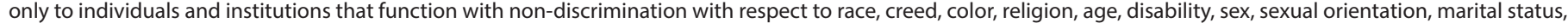

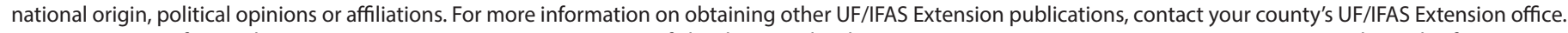
U.S. Department of Agriculture, UF/IFAS Extension Service, University of Florida, IFAS, Florida A \& M University Cooperative Extension Program, and Boards of County Commissioners Cooperating. Nick T. Place, dean for UF/IFAS Extension. 


\section{What are the symptoms of trueperella infection?}

1. Abscesses, especially of the mouth, legs, and lymph nodes

\section{Lameness}

\section{Pneumonia}

4. Common first signs of illness are open sores on the legs or at the base of antlers on mature bucks, and raspy breath associated with pneumonia.

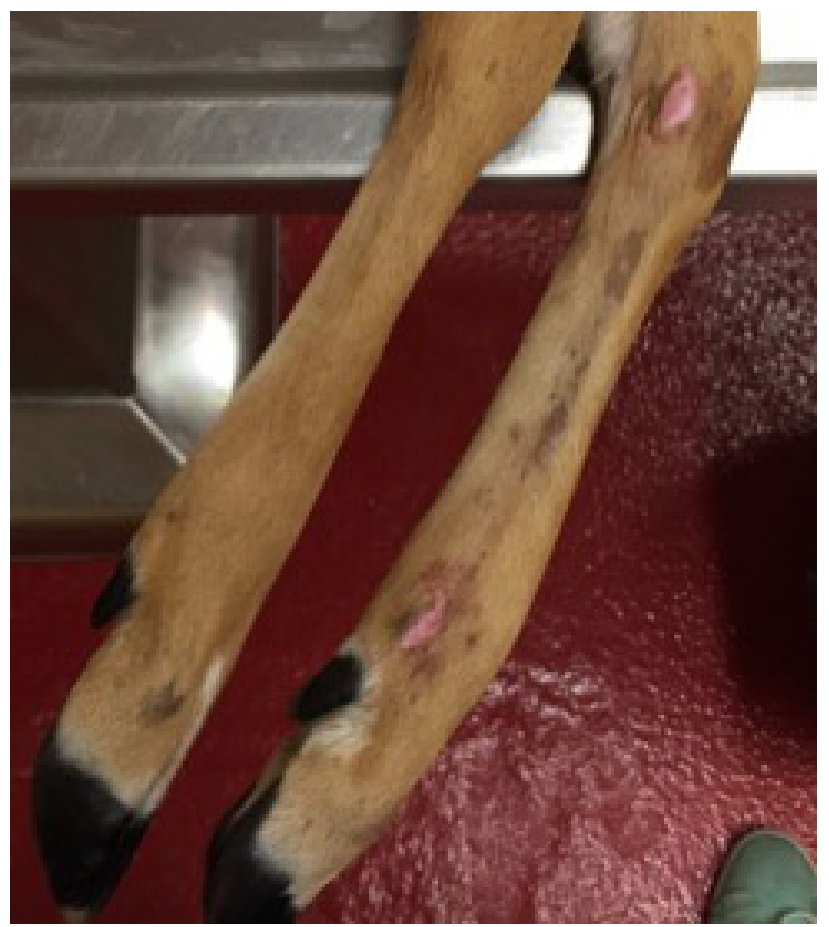

Figure 1. Untreated skin lesions from an animal that has died from trueperella.

Credits: K. D. Pothier, UF/IFAS

\section{How can I protect my herd from} common trueperella transmission risk factors?

1. Never keep infected animals in the same pen as healthy animals.

2. Do not keep deer with cattle, sheep, or goats.

3. Do not house fawns in high-density groups or on surfaces that are not easily cleaned.

4. Never re-use needles from one deer to the next.

\section{How serious is trueperella?}

It usually causes a localized infection that is easy to manage if diagnosed quickly and properly treated. If it is not treated early or if it gets into the lungs or other organs, it is often life-threatening.

\section{Can trueperella impact my entire herd?}

The disease usually affects only a few adult deer at a time, but fawns are more susceptible, and the bacteria can rapidly spread through a group of fawns. In 2016, more than ten percent of all farmed fawn deaths were attributed to trueperella.

\section{What is the treatment for trueperella?}

Early detection and treatment is the best way to prevent major illness and/or mortality. While studies have shown a high prevalence of antibiotic resistance, NuFlor (Centiofur) is the most common medication used to treat trueperella (Ribeiro et al. 2015). In addition to treating the respiratory infection, topically treating any wounds, particularly for fawns, is recommended. If you spot an external abscess, lance, drain, and flush it right away. Quick treatment of abscesses dramatically increases chances of resolution. Contact your veterinarian for specific treatment recommendations.

\section{How can I prevent trueperella in my herd?}

Environmental conditions can make animals more susceptible to diseases. Animals may be stressed due to factors such as heat and humidity, making them more susceptible to certain types of infections. Trueperella is most commonly transmitted via feces, so keep pens clean and dry and avoid stocking animals heavily to reduce the risk of infection. Early detection, rapid treatment, and in some cases isolating sick animals from the rest of the herd are key steps to reducing the risk of death for fawns that are already ill (Jost et al. 2014). Daily visual checks of your animals is an important component of animal husbandry. Look for lethargic (tired) animals and any that have separated themselves from the herd because lethargy and isolation are early indicators of illness. 


\section{Acknowledgement}

This publication is funded in part by the Renewable

Resources Extension Act (RREA).

\section{References}

Hogan, J. S., R. N. Gonzalez, R. J. Harmon, S. C., Nickerson, S. P. Oliver, J. W. Pankey, and K. L. Smith. 1999. Laboratory Handbook on Bovine Mastitis. Madison, WI: National Mastitis Council.

Jost, B. H., and S. J. Billington. 2005. "Arcanobacterium pyogenes: molecular pathogenesis of an animal opportunist." Antonie van Leeuwenhoek, 88(2), 87-102.

Nagib, S, J. Rau, O. Sammra, C. Lämmler, K. Schlez, M. Zschöck, ... and A. Abdulmawjood. 2014. "Identification of Trueperella pyogenes Isolated from Bovine Mastitis by Fourier Transform Infrared Spectroscopy." PLoS One 9(8), e104654.

Ribeiro, M. G., R. M. Risseti, C. A. Bolaños, K. A. Caffaro, A. C. de Morais, G. H. Lara, T. O. Zamprogna, A. C. Paes, F. J. Listoni, M. M. Franco. "Trueperella pyogenes multispecies infections in domestic animals: a retrospective study of 144 cases (2002 to 2012)." Veterinary Quarterly, 35(2), 82-87. 